\title{
What is the role of oral history and testimony in building our understanding of the past?
}

\section{Patricia "Chent" Gwatkin-Higson}

University of Technology Sydney, Faculty of Arts and Social Sciences, PO Box 123, Ultimo NSW 2017, Australia. Patricia.M.Gwatkin-Higson@student.uts.edu.au

DOI: $\underline{\text { https://doi.org/10.5130/nesais.v4i1.1538 }}$

\begin{abstract}
This paper examines the importance of oral story-telling in Indigenous Australian culture pre-and-post colonisation, highlighting the role of oral traditions, history and testimony in understanding the past, particularly to Indigenous Australians.
\end{abstract}

Keywords: Oral history, story-telling, testimony, Aboriginal history

Oral history and testimony has an important role in building our understanding of the past because it is as important a form of narrative as other forms of history, particularly when it comes to looking at Indigenous histories and cultures. Oral history adds another layer to our understanding of history because 'the content... is grounded in reflections on the past as opposed to commentary on purely contemporary events' (Oral History Association, 2009, para. 6) which allows a variety of interpretations and angles through which to view it. Indigenous Australian cultures are heavily reliant on oral history as a form of storytelling, learning and commemorating.

To demonstrate the importance of oral history and testimony, this essay will be looking briefly at its importance in world history in general and oral story-telling in Indigenous Australian history before European colonisation, and then focussing more closely on its role in Indigenous Australian history after colonisation. This focus will be through the lens of Reynolds' early colonial history, and the transmission across Australia of the stories of the European's arrival (1990), the big truths and little truths of history, specifically in relation to the Stolen Generations, and the role of oral history and testimonies in law, specifically in relation to the battle for Land Rights legislation in New South Wales. Through these, this essay will aim to prove the undeniable importance of oral traditions, history and testimony in understanding the past in general and its significance to Indigenous Australian history and culture in particular. 
Oral history is a narrative created by 'ordinary people' (Beard, 2017) and therefore often, incorrectly, considered a lower form of history. This is, in part, because a shared authority is different to maintain, as the history can be interpreted differently depending on the intentions of the narrator and processes of the researcher that must constantly be in consideration (Beard, 2017). The strength of Indigenous oral accounts history has often been questioned but it has been proven to be accurate and durable (Nunn and Reid, 2015). However, converting oral history to written history inevitably means that some aspects of the narrative are going to be lost, so it is important that oral history is respected and treated correctly to ensure that doesn't happen, though, as Beard (2017) states, this doesn't mean to suggest that oral history is more important than other forms of history, only that it's more volatile and should be used in conjunction with other forms of history in order to make the narrative richer.

'Oral history recording is an essential part of...cultural heritage work' because '[ $t]$ he communities...in all their diversity are a vital source of living history’ (Veale and Schilling, 2004, p. 1), and this union of official multiculturalism and unofficial multiculturalism is why oral history is so important in historical research. Oral testimonies also play a significant role in law and legal cases, at local and international levels, such as the victim impact statements that can have an impact on sentencing or oral evidence that plays a part in coming to a verdict, both of which will be explored more further on in relation to the Stolen Generations and Land Rights legislation.

Oral history is an integral part of Aboriginal and Torres Strait Islander culture and beliefs as it's how creation and culture stories, such those of The Dreaming, historical accounts, traditional ecological knowledge, and language are passed on from generation to generation and have been for thousands of years, therefore oral history and traditions are an unavoidable form of narrative when researching Indigenous cultures. Such is the importance of maintaining the links between land and story, history and the future, that when mining came to the Gove Peninsula, 'we set about connecting and securing our songlines so as to ensure our life... We reclaim and hold these places as capitals of our lands and places for our future' (Yunupingu, 2016). Yunupingu's writing demonstrates the connection between Indigenous oral storytelling and the land, as will be explored more in relation to the fight for NSW Land Rights legislation.

The oral traditions of Aboriginal Australia cannot be separated from the culture, but during times such as that of the Stolen Generations, these traditions could not be passed on because of the forced separation of Indigenous families and communities by the Australian government. This not only undermined Aboriginal communities but also the formation of 'communal memory that [was] so fundamental to Aboriginal remembrance' (Attwood, 2001). The Stolen Generations didn't only affect those who were physically separated, but also those descendants who were denied any part of the traditions, beliefs and culture that were theirs by right.

When the Europeans landed in Botany Bay and commenced their invasion, tales of them spread far and wide across the continent. Reynolds (1990) talks of the surprise of the Europeans when it seems that their arrivals in other areas and Indigenous communities were anticipated. The knowledge of their arrival had been transmitted across the continent faster than the colonists could travel themselves. European colonists in early colonial history, and still many non-Indigenous Australians today, found it difficult to reconcile the 'primitive' material culture of 'Aboriginal hunter-gatherers' with the 'sophisticated artistic life' and 'complex [system] of social organization... and... religious life' because 
of the assumptions of inferiority and the vast differences in religious beliefs and observance between Aboriginal Australia and Christianity, including that Aboriginal Australian religion appeared to lack the dogma and scriptures that Christianity had because they weren't written (Ross, 1986).

With the stories of the arrival of European colonists, Reynolds talks about the European commodities that travelled with them along the trade routes of Aboriginal Australia within months of first contact, and knowledge of these objects seemed to travel further (1990). Word of the cattle that the colonists brought with them also spread as they escaped the boundaries of the European settlements, and some English words found their way into Aboriginal lexicons, and there were 'two currents of linguistic borrowing' that 'met and merged in the centre of the continent'. There was a 'widespread cultural exchange over large areas of Aboriginal Australia' well before European colonisation, and ceremonies and traditions were exchanged and modified, and messengers travelled quickly between tribes (Reynolds, 1990). The stories of the European arrival were shared mostly, if not completely, orally as members of different tribes all over Australia met and traded goods and traditions.

Tales of colonial frontier violence were also shared, and still are today as it is, or should be, an inalienable part of colonial history. "The old people carried the knowledge of these murders inside them, and when they spoke about it they were loud and clear and we all heard their words. It was a wave of history that broke over us, and that we had to contend with' (Yunupingu, 2016). Yunupingu speaks of the importance and honour that it is to have these stories and law 'commissioned' to you, as a keeper of the stories and laws. These tales of violence have continued through Indigenous history since the European invasion, particularly, but not only, during the Stolen Generations.

The Bringing Them Home inquiry and report into the Stolen Generations was reliant on oral evidence given to the Commission. This evidence was integral in coming to the results found in the Bringing Them Home report, and its importance should not at all be diminished because of the form of narrative that it took, particularly as the emotional value of the oral testimonies was a huge part of their role in the inquiry. They shaped the Bringing Them Home report, which in turn shaped the common narrative of the Stolen Generations. The history of the Stolen Generations has been strongly contested in Australia, partly because of this. However, because of the lack of written records, oral testimonies played a bigger role in the Inquiry than they otherwise might have.

Read (2002) categorises the histories within the stories of the Stolen Generations as 'big truths' and 'little truths', which can work as a partial antidote to Attwood's view that the Bringing Them Home report and inquiry helped a common narrative about the Stolen Generations to emerge (2001). This common narrative changes the way it is talked about and discussed, which can be both positive and negative. Having a common narrative makes it easier for it to be acknowledged and discussed in general society, but it means that a lot of the 'little truths' that don't fit into the 'big truth' are immediately disregarded and are labelled as lies. A lot of the 'little truths' Read talks about are oral histories told by victims of the Stolen Generations that weren't, for a variety of reasons, public knowledge or publicly shared. These oral histories are often so personal that 'minimising oppression by denying or forgetting events...suppressing the feelings of loss and anger...was an important means of survival' (Attwood, 2001). A lot of Aboriginal communities also didn't have access to the resources necessary for making their accounts known outside of their community if they did want to 
do so. It also brings up a concern about whether all the truths should be known and accessible, even if they attract controversy from any side of the event or contradict the 'national truth' (Read, 2002).

Read believes that it's time for historians in the field to work with Aboriginal Australians to acknowledge the variations of the common narrative and to work with courts, parliament and tribunals in order to 'move the story along' to demonstrate that 'no story, however morally pure, or tragic, or heroic is ever simple' (2002), though it is debatable as to whose responsibility it is to tell the stories. This is the role that oral histories have played and will continue to play in acknowledging the tragedies European colonisation has caused the Indigenous Australians since their arrival.

Similarly to the oral evidence and testimonies used in compiling the Bringing Them Home report, Heather Goodall and Kevin Cook utilised interviews between agitators of the day to convey the history of activism that brought Land Rights legislation to NSW. Australian law didn't consider that Australia was legally owned by Aboriginal Australians, but Indigenous witnesses speaking before the Keane Committee believed otherwise, and that, when it comes to land ownership, 'Aboriginal Australians at the time conceptually separated legal ownership from "moral", or "rightful", ownership' (Lynch, 2013). When it became clear that each state would have to pass their own legislation regarding Land Rights, local communities began explaining their connection to land with a formal claim to begin rebuilding momentum for a new campaign. The land council encouraged people to write up and lodge claims, which were based on 'traditional culture...historical association and economic need' (Cook and Goodall, 2013). Aboriginal Australians are urged to 'recover a 'pride and dignity' in the ancient culture and history 'which lies in your ancestry' (McGregor, 2009). This and Yunupingu's Rom Watagnu (2016) as mentioned earlier demonstrate the importance to Indigenous Australians of having their connection to the land respected and recognised.

In Making Change Happen (2013), Cook and Goodall's interviews are used to tell the history in the activists' own words so that those interviewed still have control over their story, their reasoning and their methods in achieving land rights in New South Wales. It ensures that the individuals voices are still maintained and ensures that ownership remains with them, though Cook and Goodall have been trusted with keeping these stories safe for the benefit of researchers in the future. These interviews help us to understand the social values of the time and allows us to gain an insight into the changes in people's values and the places they consider important through their lives, experiences, and wider Indigenous Australian culture and history, and lets us learn from them (Veale and Schilling, 2004). A lot of oral history is location-based, and vice versa in this specific case, and people are shaped by the places they inhabit. This link is why Cook and Goodall tell the history of NSW Land Rights legislation partially through interviews.

Of the Nuremberg trials, Dr. Bruce M. Stave said that ' $[a] n$ oral history gives you the story of the average folks who were there...[y]ou read about [American attorney and judge] Robert Jackson in the newspapers and history books, but you don't often read about the security guard or the translator, the people who really made things happen...[t]he oral history helps to fill in gaps' (Hamilton, 1999) and this can easily be applied to the Stolen Generations, NSW Land Rights legislation, and more generally Indigenous Australian history post-colonisation. 
The role of oral history and testimony is of utmost importance in building our understanding of the past, particularly in the study of Indigenous Australian culture, history and practices. Oral traditions are an undeniable aspect of Aboriginal culture that it's impossible to avoid, and it has to be acknowledged and respected. It's power and significance are demonstrated in the records of early colonial Australia when the European colonists reported that news of their arrival or European commodities in different parts of the country often preceded the colonists themselves as Reynolds talks about in The Other Side of the Frontier (2002). It's also proven in the interviews, testimonies and 'little truths' that came out of the Stolen Generations and shaped the Bringing Them Home Report and Inquiry, and then later the fight for Lang Rights legislation in New South Wales. Oral history as a narrative is often discredited due to its apparently unreliable nature, but it gives a depth to our understanding of history that is as important as the 'big truths', statistical facts and written records.

\section{Reference List}

Attwood, B. 2001 ' 'Learning about the truth': The stolen generations narrative' in B. Attwood and F. Magowan (eds) Telling Stories: Indigenous history and memory in Australia and New Zealand, Wellington: Bridget Williams Books, pp. 183-212

Beard, M.R. 2017, 'Re-thinking oral history - a study of narrative performance' in Rethinking History, vol. 21, no. 4, UK: Taylor \& Francis Group, pp. 529-548

Cook, K and Goodall, H. 2013 'Part 3: Land Rights NSW 1980s' in Making Change Happen: Black and white activists talk to Kevin Cook about Aboriginal, Union and Liberation Politics, Canberra: The Australian National University, pp 175-235

Hamilton, R.A. 1999, Q\&A/Bruce M. Stave; Collective Memories of Nuremberg, The New York Times, viewed $17^{\text {th }}$ June $2018<$ https://www.nytimes.com/1999/02/14/nyregion/q-a-bruce-m-stavecollective-memories-of-nuremberg.html>

Lynch, M.E. 2013, “It is our land and has always been our land”: How Aboriginal Australians conceptualised land rights in the Keane Committee' in Macquarie Matrix, vol. 3, no. 2, pp. 30-51

McGregor, R. 2009, 'Another Nation: Aboriginal activism in the Late 1960s and early 1970s' in Australian Historical Studies, vol. 40, no. 2, pp. 343-360. https://doi.org/10.1080/10314610903105217

Nunn, P.D. and Reid, N.J. 2016, 'Aboriginal Memories of Inundation of the Australian Coast Dating from More than 7000 Years Ago' in Australian Geographer, vol. 27, no. 1, pp. 11-47. https://doi.org/10.1080/00049182.2015.1077539

Read, P. 2002, 'Clio or Janus? Historians and the Stolen Generations' in Australian Historical Studies, vol. 33, no. 118, pp. 54-60. https://doi.org/10.1080/10314610208596179

Reynolds, H. 1990, The other side of the frontier: Aboriginal resistance to the European invasion of Australia, Ringwood: Penguin, pp. 5-29 
Ross, M.C. 1986, 'Australian Aboriginal Oral Traditions’ in Oral Tradition, vol. 1, no. 2, pp. 231-271

Veale, S. and Schilling, K. 2004, Talking History: Oral history guidelines, Hurstville: The Department of Environment \& Conservation (NSW)

Yunupingu, G. 2016, 'Rom Watagnu: An Indigenous leader reflects on a lifetime following the law of the land', The Monthly, viewed $12^{\text {th }}$ June 2018

https://www.themonthly.com.au/issue/2016/july/1467295200/galarrwuy-yunupingu/rom-watangu

(C) 2018 by the author(s). This article is distributed under the terms and conditions of the Creative Commons Attribution license (http://creativecommons.org/licenses/by-nd/4.0/). 